ADALAH : Buletin Hukum \&

Keadilan

Buletin Hukum \& Keadilan

@adalahuinjkt

\title{
Korelasi Musyawarah Dalam Perwujudan Demokrasi Di Indonesia
}

\author{
Alda Shafira Rani Larasati*
}

Samuel P. Huntington mengartikan demokrasi sebagai keputusankeputusan kolektif yang kuat yang dibuat oleh orang-orang yang dipilih melalui pemilihan umum yang adil, jujur dan berkala. Dalam sistem itu para calon secara bebas bersaing untuk memperoleh suara di mana hampir semua penduduk dewasa berhak memberikan suara. Sedang Joseph A. Schumpeter memandang demokrasi melalui sudut pandang yang berbeda. Schumpeter melihat demokrasi sebagai suatu "metode". Menurutnya, demokrasi tidak lain adalah sebuah prosedur kelembagaan untuk mencapai keputusan politik. Di mana setiap individu memiliki hak membuat keputusan melalui perjuangan yang kompetitif dalam rangka memperoleh suara rakyat (Nugroho,2013: 250-251).

Dalam hidup bersama, mutlak perlu menegakkan musyawarah dalam menghadapi dan memecahkan masalah-masalah bersama. Makin besar sesuatu kelompok, maka semakin besar pula perlu ditegakkannya musyawarah. Ia merupakan sendi kehidupan masyarakat yang digunakan sebagai prinsip dan termasuk syariat. Artinya, musyawarah termasuk ketentuan Allah yang harus ditegakkan di muka bumi. Dengan kata lain, meninggalkan musyawarah berarti meninggalkan

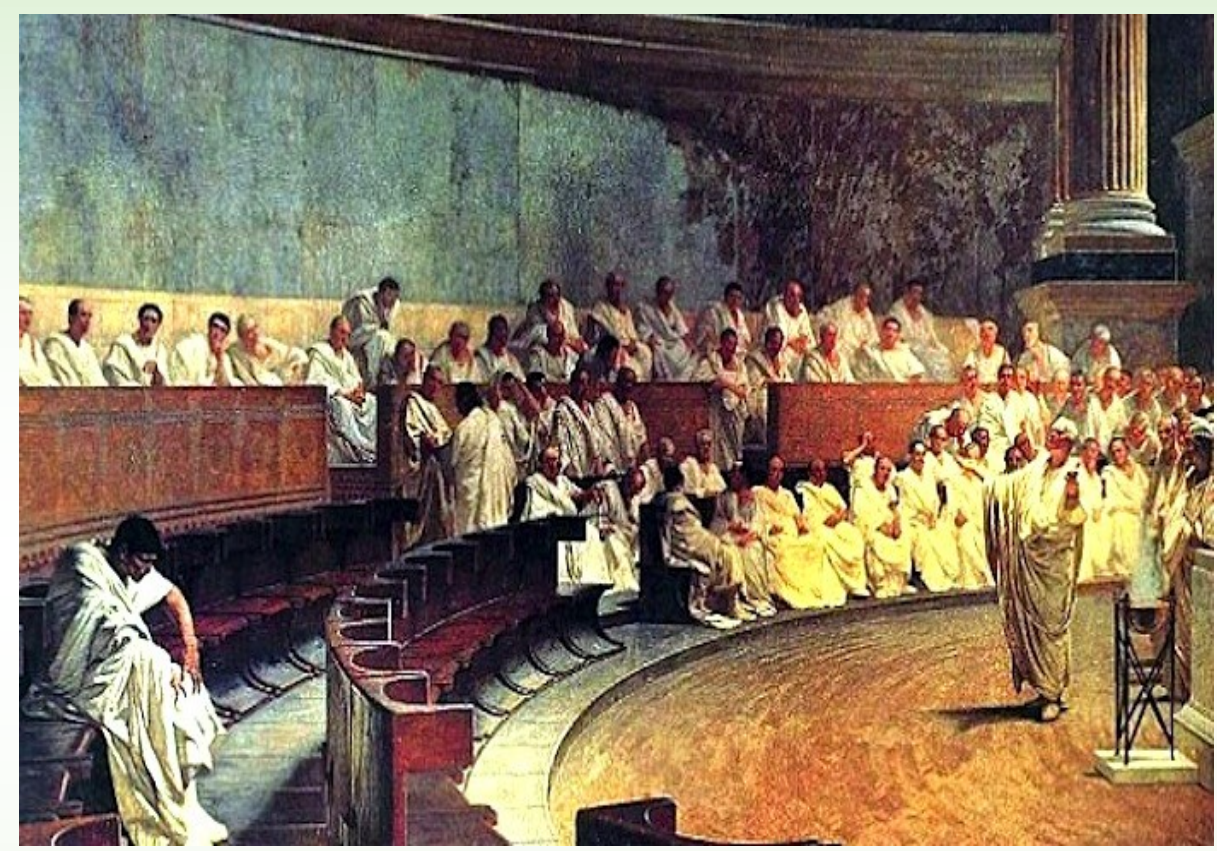

salah satu segi syariat (Hanafi, 2013: 230).

Menurut Muhammad Hanafi dalam Jurnal Cita Hukum perbincangan mengenai persamaan dan perbedaan antara musyawarah dan demokrasi tidak pernah berhenti sampai saat ini. Sehingga membuat semakin berkembangnya ilmu politik dan ketatanegaraan. Pemikiran-pemikiran

yang bermunculan mengenai persamaan dan perbedaan kedua ajaran ini terus semakin tajam, akan tetapi pada tatanan pelaksanaannya masih jauh dari cita-cita, terutama mengenai pelaksanaan musyawarah pada tingkat kehidupan berbangsa dan bernegara. Pandangan mengenai persamaan dan perbedaan antara musyawarah dan demokrasi dapat dikelompokkan kepada tiga kelompok pemikiran, yaitu sebagai berikut: Pertama, kelompok pemikiran yang berpandangan bahwa antara musyawarah dan demokrasi adalah sama. Kedua, kelompok pemikiran yang berpandangan bahwa antara musyawarah dan demokrasi selain memiliki persamaaan, juga terdapat perbedaan pada hal-hal tertentu. Ketiga, kelompok pemikiran yang berpandangan bahwa antara musyawarah dan demokrasi adalah berbeda (Hanafi, 2013: 242-243).

Pemahaman untuk kelompok pemikiran yang pertama melihat bahwa nilai-nilai yang terkandung 
di dalam demokrasi sama dengan nilai-nilai dalam musyawarah yang berdasarkan kepada nilai-nilai ajaran Islam, seperti keadilan, persamaan, dan nilai-nilai lainnnya. Pemikiran seperti ini lebih melihat musyawarah dari sudut pandang demokrasi, pandangan ini sangat banyak terdapat dalam setiap materi ajar ilmu politik dewasa ini. Pada kelompok pemikiran kedua yang berpandangan bahwa selain terdapatnya persamaan antara musyawarah dan demokrasi, terdapat pula beberapa perbedaan pada halhal tertentu, terutama yang berkaitan dengan perintahperintah agama, sehingga terbangun pemikiran untuk lebih teraturnya pelaksanaan demokrasi harus berdasarkan kepada aturan-aturan perintah Tuhan, pemikiran ini terkenal dengan sebutan nomokrasi. Kemudian pada kelompok pemikiran ketiga yang berpandangan antara

musyawarah dan demokrasi adalah berbeda. Adapun perbedaannya adalah sebagai berikut: Pertama, Musyawarah merupakan perintah Allah Swt di dalam Alquran kepada rasul-Nya yang harus dilaksanakan oleh umatnya. Sementara demokrasi merupakan hasil pemikiran Barat, dengan demikian demokrasi merupakan identitas Barat bukan identitas Islam. Kedua, dalam musyawarah, hal-hal baik perintah maupun Kedudukan Musyawarah dan Demokrasi di Indonesia larangan yang telah jelas hukumnya telah ditetapkan Allah SWT dan Rasulnya, tidak boleh dimusyawarahkan kembali, akan tetapi langsung dilaksanakan. Sementara di dalam demokrasi masih mengabaikan hukum-hukum Allah yang sudah permanen. Hal-hal yang telah jelas dilarang dalam agama masih dapat dibahas atau divoting sebagai bentuk negosiasi untuk boleh dilaksanakan atau tidak (Hanafi, 2013: 242-243). Walaupun tetap diakui, sejatinya demokrasi yang menjadi dasar berpijak rakyat dalam bersuara selalu menginginkan kebaikan pada mayoritas orang, bukan hanya segelintir orang saja (Yunus, 2017: 22). Suara rakyat adalah suara Tuhan.

Menurut penulis, Musyawarah dan Demokrasi saling berkaitan satu sama lain. Keduanya merupakan dua metode penyelesaian masalah kehidupan dunia yang berbeda, bahkan sangat berlawanan. Musyawarah menghasilkan suatu keputusan yang disebut mufakat, sedangkan demokrasi menghasilkan suatu keputusan guna penetapan pihak yang memenangkan pemilihan yang dilaksanakan. Musyawarah harus dapat menampung masukan-masukan dari orang lain agar mendapatkan keputusan yang disepakati antara satu sama lain dan tidak ada yang tersinggung akan pendapat yang dipilih tersebut. Negara tanpa adanya Musyawarah tidak akan dapat menjadi negara yang makmur, maju dan mempunya nilai-nilai yang baik di mata dunia.

Oleh karenanya, dalam suatu demokrasi, rakyat harus ikut serta dalam memerintah yaitu melalui perantara wakil-wakil yang terpilih dan harus mengutamakan hak dan kewajiban. Rakyat merupakan pemegang kekuasaan tertinggi dalam suatu 